\title{
Sharing via Low-Cost Discovery in Global Effort for Combat Diseases: Simple Chemical Routes for Lead Compounds Using Biomass Driven Building Blocks
}

\author{
Galal A. M. Nawwar*, Randa H. Swellam and Hoda S. Othman \\ Green Chemistry Department, Chemical Industries Research Division, National \\ Research Centre, Al Buhouth St., Dokki, Giza, Egypt PO box 12622, Dokki, Giza, \\ Egypt.
}

\begin{abstract}
MONG various participations in the global efforts for drugs, preservatives and pesticides discovery, there are cost-effective simple synthetic routes via productive methods to synthesize potent biologically active compounds, utilizing biomass driven starting compounds. This eco-friendly approach appropriates also researchers where shortage in research fund and facilities. Versatile precursors such as 3-oxoalkane carboxylates, activated nitriles and a, $\beta$ unsaturated ketones, were utilized for the facile synthesis of various biologically interesting small molecules. In this review, we highlight representative synthetic findings for bioactive leads arising from our continuous attempts with this approach. Further development by industry and academia through lead optimization will produce new active ingredients to face contiguous hazard biological challenges and resistance of microbes and insects. Many other researchers have made many great achievements in each of these subjects, but these are beyond the scope of this review.
\end{abstract}

Keywords: Sustainability, Biomass, Organic synthesis, Bioactive small molecules.

\section{Introduction}

It is clearly appeared beyond doubt that research plays a significant role in shaping the societies' future as never before. One of the problems for most African regions, for example, is the poor quality and quantity of research-based education, as well as low level of research funding. Hence, African researchers produce only around one percent of the world's research [1]. Research and discoveries allow universities to better serve their respective societies, and result in direct benefits, fuelling economic growth. A new report from the World Bank and science publisher Elsevier looked at Africa's research performance over this last decade, and shows that the quality and quantity of that research is improving [2]. The report concludes by recommending that African governments should accelerate support to research in Africa to build the necessary human capital to solve African problems. In addition, many African students leave their countries to study at universities in Europe, Asia and America and do not return $[3,4]$. Thus, existing African scientific communities need to be nurtured. In this context, different research scenarios should be tested and polarized to overcome obstacles facing development through applying research.

Synthetic approaches utilizing biomass represents an important alternative to the non-sustainable fossil resources in producing chemicals and fuels, at the same time that the interest in the environment increases and search for new active ingredients needs extensive multidiscipline research and huge fund [5]. Particularly, plant-derived biomass is a reproducible and low environmental-loading resource, produced from $\mathrm{CO}_{2}$ and water via photosynthesis using sunlight [6,7]. Biomass, including cellulose, lignin and chitin, represents the most abundant renewable carbon resource on the earth and could offer a wide platform of starting compounds and substrates for the production of bulk and specialty chemicals [5], that help researchers especially in developing countries to use them and discover new bioactive small molecules to participate in the global efforts for discovery new drugs, food preservatives, and pesticides (cf. Fig.1) [8].

*Corresponding author e-mail: gnawwar@yahoo.com

Tel: 202 33335494; Fax: 20233370931

DOI:10.21608/ejchem.2018.3803.1328

C2017 National Information and Documentation Center (NIDOC) 


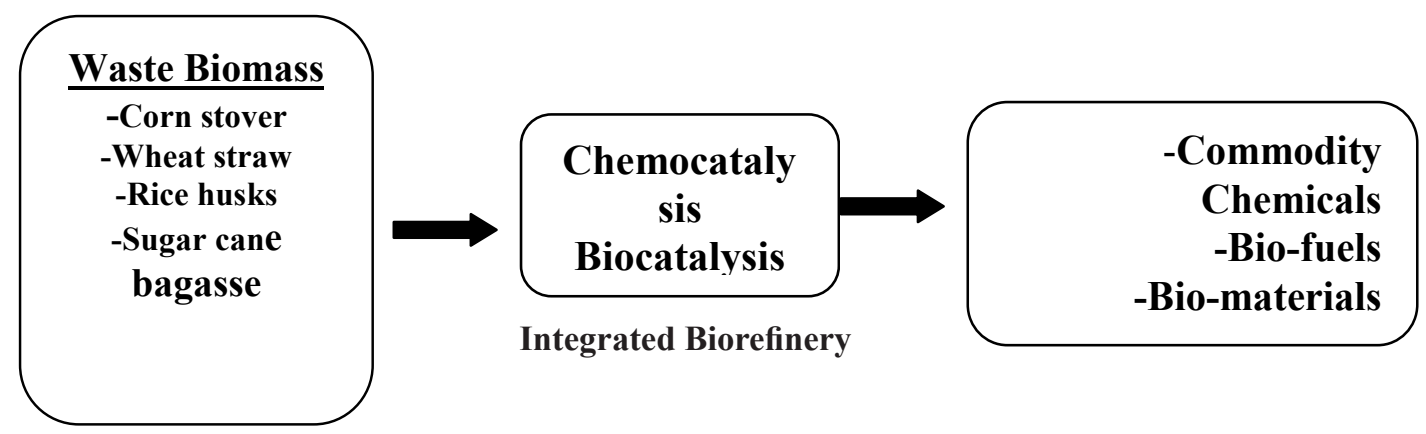

Fig.1. The bio-based economy.

Cellulose for example, is a polymer of glucose units linked by $\beta$-1,4-glycosidic bonds. It could be easily hydrolyzed affording glucose which considered a versatile precursor to valuable chemicals such as biodegradable plastics and ethanol (cf. Fig.2) [6].

Hence, the conversion of cellulose has attracted world-wide interest. Catalytic conversion of biomass into glucose, polyols, 5-hydroxylmethyl furfural (HMF), alkyl glucosides and aromatic compounds have been extensively studied. Meanwhile, transformations of biomass into valuable organic acids including lactic acid, levulinic acid, formic acid, acetic acid and gluconic acid have also received considerable attention. These acids, especially, ranging from $\mathrm{C} 1$ to $\mathrm{C} 6$, play a vital role in the industry of chemistry as a food additive, and a key industrial chemical for polyvinyl acetate and synthetic fibers production [5]. In this context, Hemicelluloses, types of plant cell wall polysaccharides also can be easily hydrolyzed into pentose (xylose and arabinose) and hexose (glucose, galactose, and mannose), and transformed into fuel ethanol and other value-added chemicals, such as 5-hydroxymethylfurfural (HMF), furfural, levulinic acid, and xylitol [9].

It's worth to mention that, among reasons that make giant firms searching for bioactive molecules discovery interested in active compounds driven from this simple synthetic approach, are almost ease of products purification, high products yield, absence of reaction side products. Additional reason for this interest is the simple technological facilities needed for their industrial scale production. There is a considerable number of approved biomass driven drugs in the market as well as compounds currently going through different clinical phases or registration statuses [10].

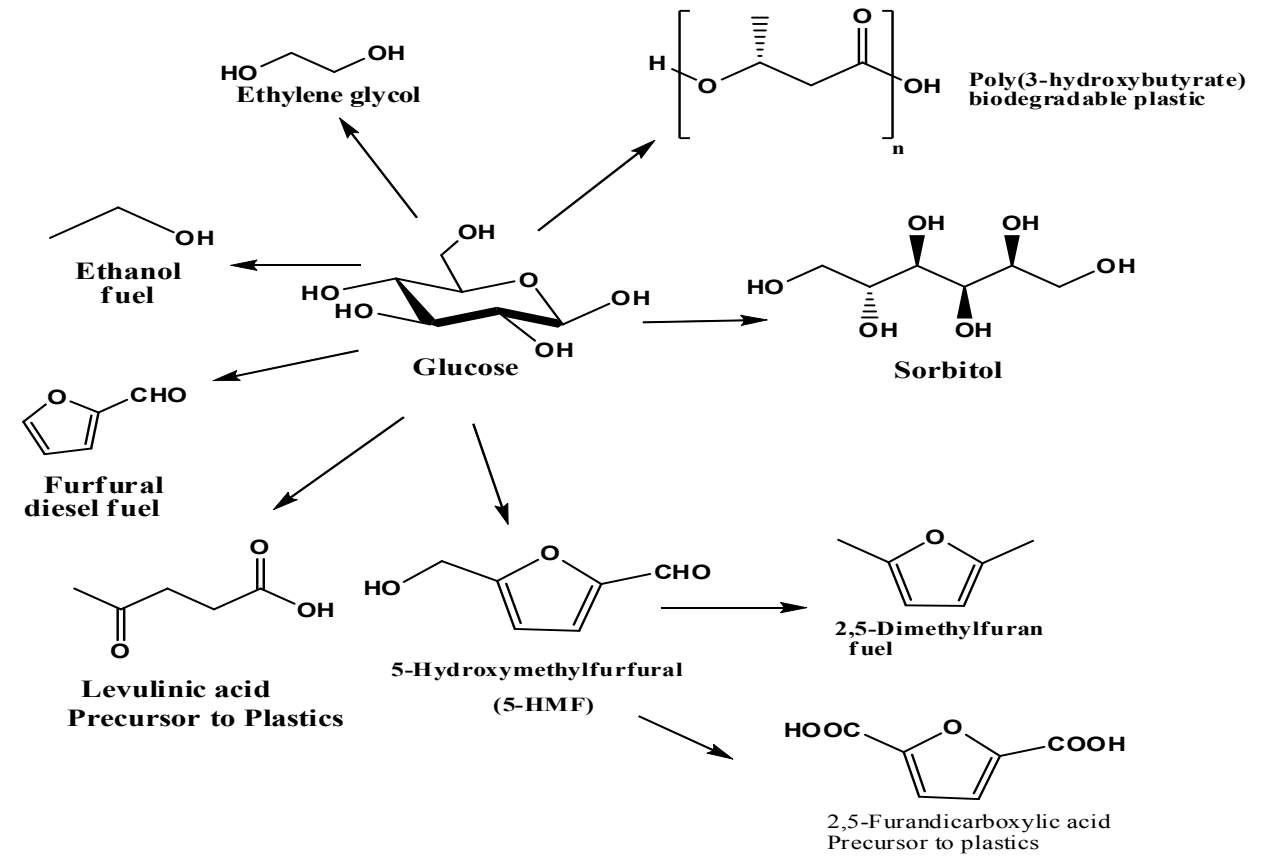

Fig.2. Derived chemicals from glucose. 
Infectious diseases, which scientists combat by bioactive small molecules among other several tools, are the most leading causes of human morbidity and mortality for most of human existence. Over the past three decades, our research program has been centered on seeking simple synthetic chemistry that can drastically increase efficiency toward low cost-discovery and sustainability. This review focuses on discovering chemistry that can directly and efficiently utilize natural feed stocks without extensive derivatization. This review briefly summarizes our efforts in the synthesis of antibacterial, antifungal, antitumor, Analgesic and antiinflammatory, antioxidants besides insecticides and molluscicides lead molecules in an attempt to participate in the global effort to combat diseases. It is worth to mention that the poly functionality of the presented lead structures in this review facilitates their chemical transformation for the lead optimization study.

\section{A) Simply synthesized lead antibacterial compounds}

Antibacterial agents are compounds or substances that kill or slow down the growth of bacteria, they save countless lives and make enormous contribution to the control of infectious diseases since the beginning of antibacterial era [11]. Antibiotics perturb important bacterial biochemical processes, and they can be classified based on the cellular component or system they affect, in addition to whether they induce cell death (bactericidal drugs) or merely inhibit cell growth (bacteriostatic drugs). Most current bactericidal antimicrobials inhibit DNA synthesis, RNA synthesis, cell wall synthesis, or protein synthesis.

During recent years, the overuse and misuse of antibiotics stimulated the more rapid emergence of antibiotic-resistant bacteria (ARB) and antibiotic resistant genes (ARGs), reducing their therapeutic potential against human and animal pathogens [12]. World Health Organization characterizes antimicrobial resistance as growing public health threat of broad concern to countries and multiple sectors that must be managed with the utmost urgency [13]; situation caused the need for developing new and potent antimicrobial agents. In this attempt, we utilized pyrogallol, from biomass driven gallic acid, to synthesize a series of pyrazoles containing gallate moiety. These pyrazoles were tested for antibacterial activity and the obtained data revealed that compound 4 showed a comparable effect to a well-known antibacterial agent [14].

Glycine, cinnamaldehyde and oleic acid also are biomass driven building blocks. They were utilized in the synthesis of the most effective antibacterial agents 8 and 9 among several synthesized and tested compounds $[15,16]$.<smiles>Oc1cccc(O)c1O</smiles>

1 (i) $\mathrm{Ac}_{2} \mathrm{O} / \mathrm{ZnCl}_{2}$

(ii) DMS/ KOH

(iii) $\mathrm{PhNHNH}_{2} / \mathrm{AcOH}$<smiles>COc1ccc(/C(C)=N/c2ccccc2)c(O)c1OC</smiles>
$\mathrm{POCl}_{3} / \mathrm{DMF}$<smiles>COc1ccc(-c2nn(-c3ccccc3)cc2C(=O)O)c(O)c1OC</smiles>
4<smiles>COc1ccc(-c2nn(-c3ccccc3)cc2C=O)c(O)c1OC</smiles>

Scheme 1: Utilization of pyrogallol in the synthesis of lead antimicrobial pyrazole. 


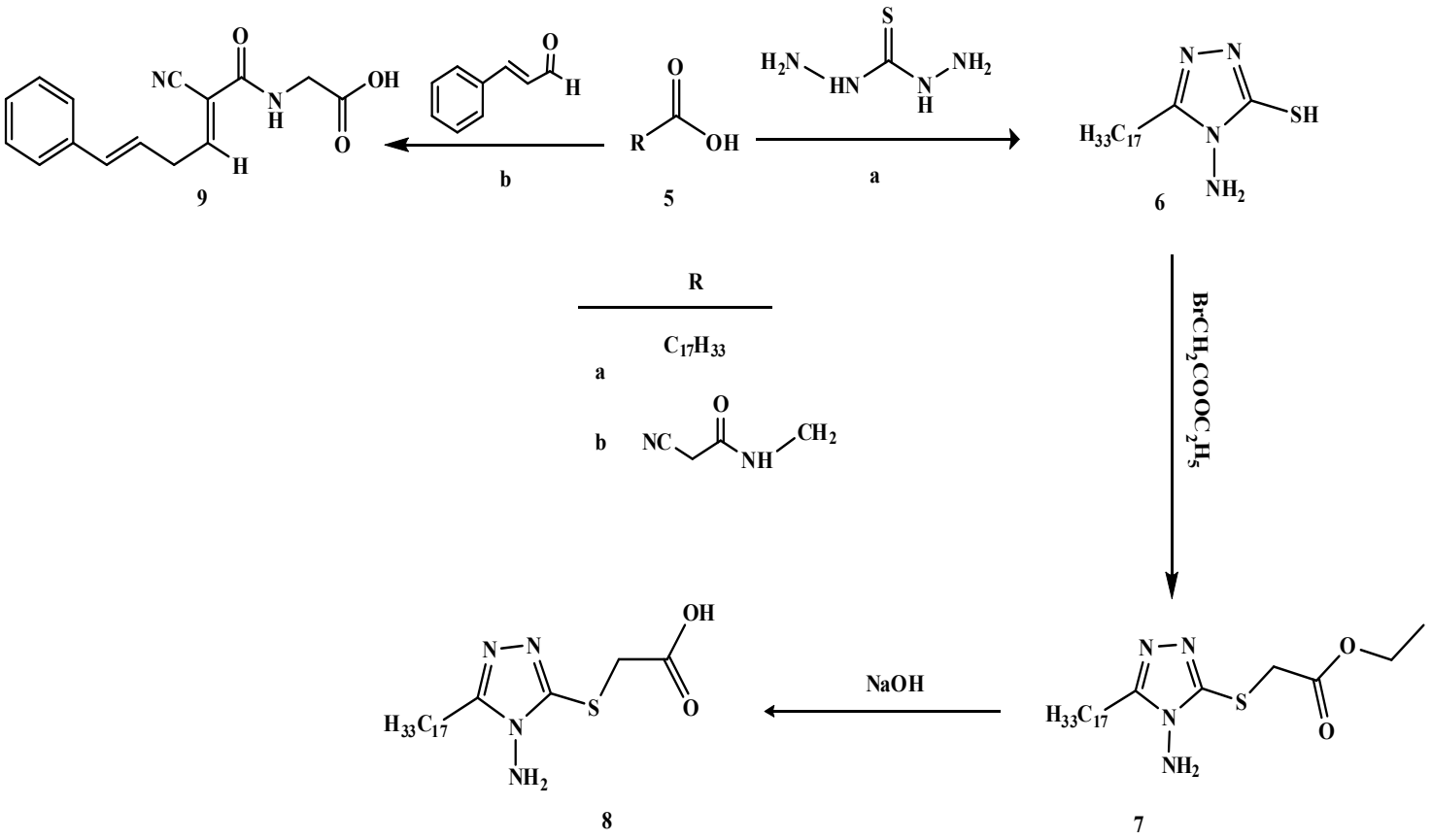

Scheme 2: Glycine, Cinnamaldehyde and oleic acid as precursors for synthesis of potent antibacterial (8).

Terephthalic acid obtained from recycling of plastic bottles waste (PET)was utilized to synthesize 1,3,4-Oxadiazole $\mathbf{1 3}$ which showed high antibacterial activity [17].

B)Facile synthesized lead Antifungal compounds:

Fungi Kingdom is one of the most diverse groups of organisms on Earth[18]; it includes some of the most important organisms, both in terms of their ecological and economic roles. By breaking down dead organic material, they continue the cycle of nutrients through ecosystems. In addition, most vascular plants could not grow without the symbiotic fungi, or mycorrhizae, that inhabit their roots and supply essential nutrients. Other fungi provide numerous drugs (such as penicillin and other antibiotics), foods like mushrooms, truffles and morels, and the bubbles in bread, champagne, and beer. Although there are millions of different fungal species on Earth, only about 300 of those are known to make people sick. They became important human pathogens only in the late 20th century, primarily in hosts with impaired immunity as a consequence of medical interventions or HIV infection [19].

In the past few decades, a worldwide increase in fungal infections has been observed with a rise in the resistance of some species of fungi toward different fungicides used in medicinal practice [20]. Candida albicans (C. albicans), an example of resistant fungus to antifungal agents, is the most common fungal pathogen in clinical settings and is responsible for infections that can affect the skin and the mucosa or cause life-threatening systemic disease [21]. The mortality among patients with invasive candidiasis is as higher than $40 \%$, even when patients receive antifungal [22]. Therefore, it is important to find new antifungal agents especially that are driven from biomass.

One of our trials to do so is the utilization of acetic acid which is produced from biomass refining or fermentation. Its derivatives, for example, ethyl cyanoacetate and cyanoacetic acid are important building blocks in organic synthesis. Thus, Arylidine derivative 16a and 3-(benzothiazol-2-yl)dihydropyridine 17b, simply synthesized from $N$-acetylbenzothiazol-2-ylacetohyrazide 15, exhibited remarkable antifungal activity [23].

In continuation, compounds 22a,b showed remarkable fungicidal activity. They were synthesized by the reaction of triazole 18 or triazine 19 with ethylcyanoacetate via addition with subsequent self-cyclization to afford 20. Compound $\mathbf{2 0}$ was successfully added to carbon disulphide to produce compound $\mathbf{2 1}$ in good yield. Finally, potent fungicide $\mathbf{2 2}$ could be obtained from the reaction of $\mathbf{2 1}$ with hydrazine hydrate [24]. 


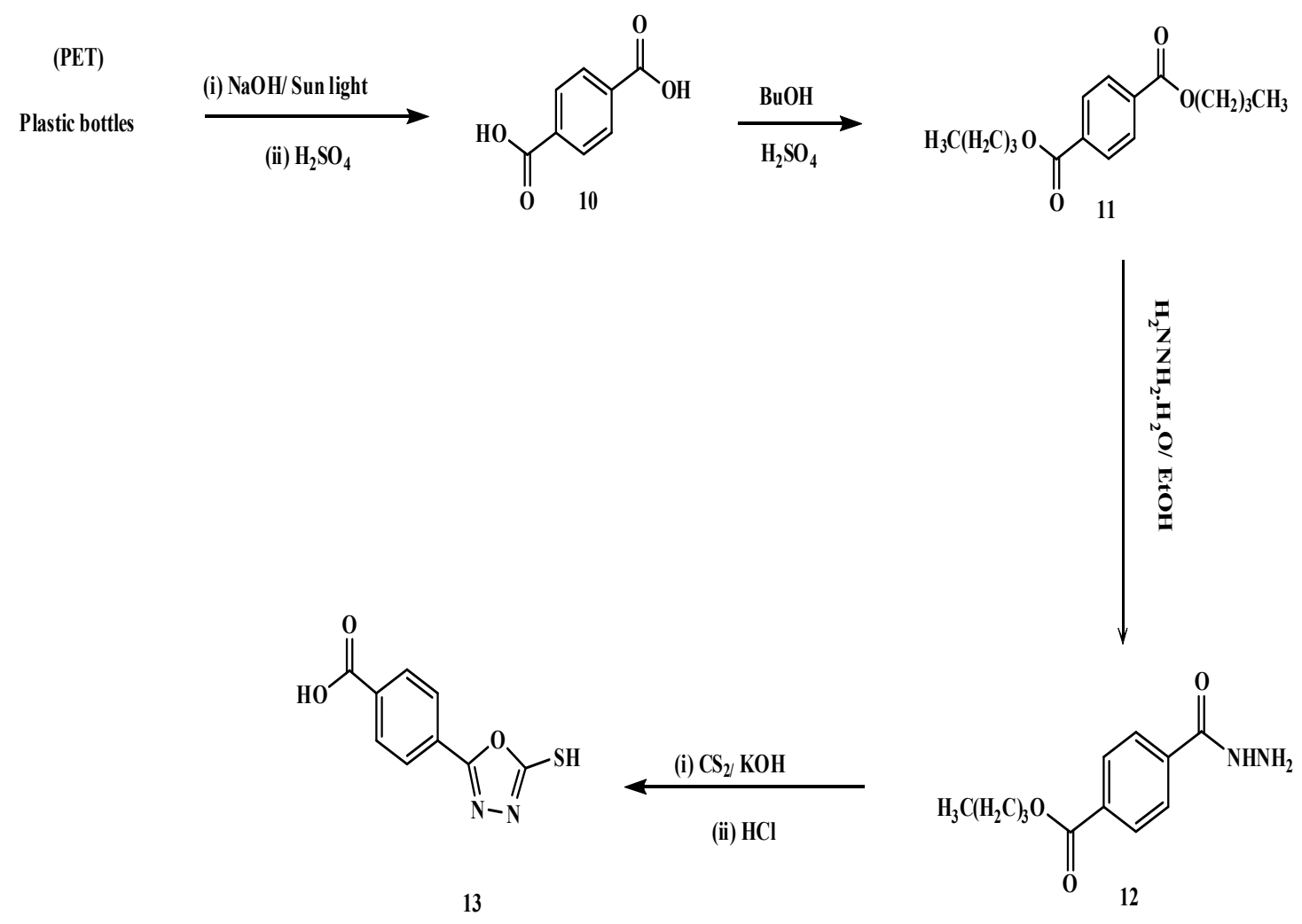

Scheme 3: Recycling of plastic bottles to synthesize lead antibacterial oxadiazole (13).

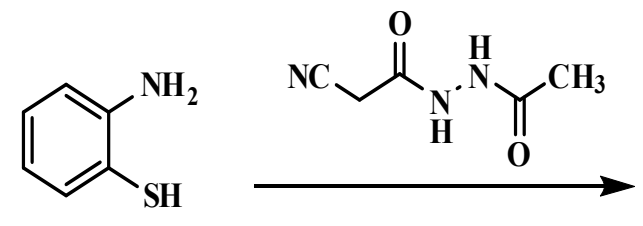

14<smiles>CC(=O)NNC(=O)Cc1nc2ccccc2s1</smiles>

15

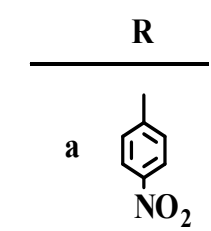

b<smiles>[R]C1C(C#N)=C(N)N(NC(C)=O)C(O)=C1c1nc2ccccc2s1</smiles>

17

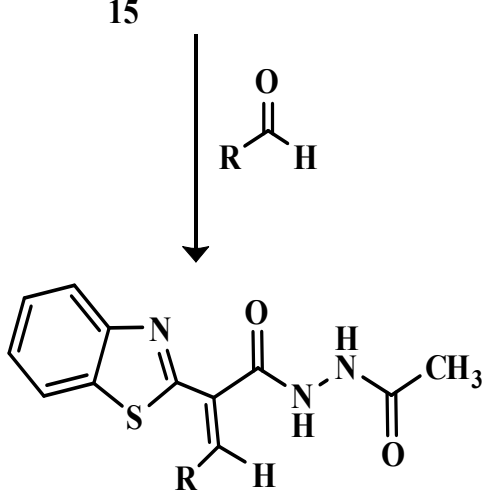

16

Scheme 4 : Utilization of some acetic acid derivatives for the synthesis of lead antifungal (17).

Egypt. J. Chem. 61, No.5 (2018) 
In the same context, reaction of ethylcyanoacetate with ortho diamine resulted in synthesis of compound 23 which was utilized as a starting material to give compound 24. Compound 24 showed remarkable antifungal activity as well as Compound 25a which exhibited potent antifungal activity with low MIC comparing with Cefoperazone and Fluconazole as reference drugs $[25,26]$. It is worth to mention that the pyridoimidazole $\mathbf{2 5} \mathbf{b}$, as isostyer of $\mathbf{2 5}$, was more active as a fungicide than 25a and further research are under investigation. Compounds $\mathbf{2 6}$ were obtained via the imidazole moiety active nitrogen nucleophilic addition to the isothiocyante molecules with subsequent ring closure involving the cyano group [25].
On the other hand, fatty acids are renewable resources that can be obtained from oleo biomass. Some of these acids were converted to their esters to participate in the synthesis of new series of biological active compounds 29 . The antifungal activity of them was screened and some of the newly synthesized compounds showed a broad spectrum of activity. The (SAR) studies demonstrate that the fatty chain in the synthesized compounds plays a crucial role in their biological activities. The increase in the number of carbon atoms of the side chain decreases the antimicrobial activity [26].<smiles>CCOC(=O)C[Y]1nnc2sc(CC(=O)OCC)nn12</smiles><smiles>Cc1nnc(S)n(N)c1=O</smiles>

20 b $\left(\mathrm{C} \mathrm{CH}_{3}\right)-\mathrm{CO}$

19<smiles>CSc1[nH][nH]c(=O)c1-c1nn2[Y]nnc2s1</smiles><smiles>CCOC(=O)C(C(C)=S)c1nn2[Y]nnc2s1</smiles>

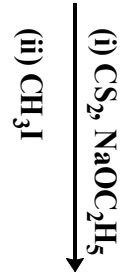

Scheme 5: Synthesis of lead fungicide 22.

Pyrogallol, obtained from biomass driven gallic acid, was converted to pyrogallol actophenone to synthesize new series of pyrazolesincorporating $1,3,4$ oxadiazole moiety. It has been synthesized utilizing our recently reported 4-formyl pyrazole which prepared from $\mathbf{2}$ via Vilsmeier reaction. A solution of compound 2, ethanoli $\mathrm{cNaOH}$ and hydrogen peroxide was refluxed to afford $\mathbf{4}$ that gave compound 30 when heated under reflux with conc. $\mathrm{H}_{2} \mathrm{SO} 4$ in absolute ethanol or with thionyl chloride in benzene. By the reaction of $\mathbf{3 0}$ with hydrazine hydrate followed by the addition of carbon disulfide and potassium hydroxide, compound $\mathbf{3 2}$ was synthesized and it was found to be the highly active fungicidal agent in this series [14].
Lead Antiviral molecules obtained via same mentioned approach

Viral diseases are extremely widespread infections. Some familiar viral diseases include common cold, influenza, chickenpox, herpes, gastroenteritis (stomach flu), human immunodeficiency virus (HIV/AIDS), and hepatitis. They can lead to serious, and potentially life-threatening complications, it was estimated that viral infections are responsible for more than $60 \%$ of the illnesses occurring in developed countries. Antivirals are compounds used since the 1960 s that can interfere with viral development. It was estimated that viral infections are responsible for more than $60 \%$ of the illnesses occurring in developed countries [27]. Antivirals display 
<smiles>N#CCc1nc2ccc[Y]c2[nH]1</smiles><smiles>N#C/C(=N\O)c1nc2c([nH]1)NC=CC=C2</smiles>

25<smiles>N#C/C(=C\NC(=O)O)c1nc2ccccc2[nH]1</smiles>

24<smiles>CCN1C(=N)/C(=N\O)c2nc3cccnc3n2C1=S</smiles>

26

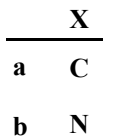

b $\mathbf{N}$

Scheme 6: New antifungal, analgesic and antiinflammatiry agents utilizing acetic acid derivative.<smiles>[R2]OC([R])=O</smiles>

27<smiles>[R]c1nnc([Hg])o1</smiles>

29<smiles>[R]C1=NNC(=C)O1</smiles>

Scheme 7: Utilization of fatty acids in the synthesis of new series of antif ungal compounds.<smiles>COc1ccc(-c2nn(-c3ccccc3)cc2C(=O)O)c(O)c1OC</smiles><smiles>CCn1cc(C(=O)OC(=O)c2cn(-c3ccccc3)nc2-c2ccc(OC)c(OC)c2O)c(-c2ccc(OC)c(OC)c2O)n1</smiles><smiles>COc1ccc(-c2nn(-c3ccccc3)cc2-c2nnc(S)o2)c(O)c1OC</smiles><smiles>COc1ccc(-c2nn(-c3ccccc3)cc2C(N)=O)c(O)c1OC</smiles>
31

32

Scheme 8: Lead antifungal utilizing Pyrogallol.

Egypt. J. Chem. 61, No.5 (2018) 
various mechanisms of action, and while some of them enhance the animal immune system, others block a specific enzyme or a particular step in the viral replication cycle. Antiviral drugs play an important role in fast-spreading epidemics; however almost all antivirals are subjects to drug resistance as the pathogens mutate over time, becoming less susceptible to the treatment. In addition, the most important condition that must be possessed as an antiviral drug is to inhibit the virus in the cell and have no effect on the normal metabolism of cell. At present, a large number of antiviral drugs have serious side effects, which makes it difficult to develop effective antiviral agents with little side effects [28]. Therefore, there remain important medical needs to improve upon the current therapy as well as those there exists no treatment [27].

In this context, West Nile Virus (WNV), a human pathogen rapidly expanding worldwide, is a member of Flaviviruses, a genus that infects millions of people worldwide and is the cause of tens of thousands of fatalities annually [29]. Infection in humans is generally asymptomatic or causes a mild febrile disease in about $20-30 \%$ of cases. The most severe cases of WNV infection result in encephalitis or meningitis. Around 10\% of cases of neuroinvasive disease are fatal and the survivors may suffer from long-term cognitive and neurological impairment [30]. Unfortunately, there is no effective human vaccine or effective antiviral therapy available for WNV.

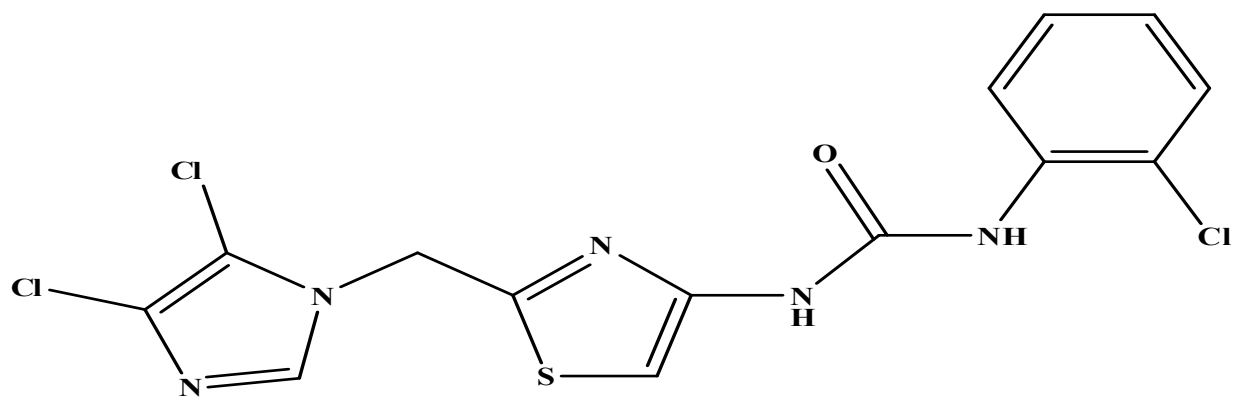

33

Scheme 9: Potent antiviral incorporating urea moiety.

Among the continued medicinal chemistry efforts done, Paul R. Young et al. [31]. reported the in silico screening of small molecule libraries using the dengue virus envelope $\mathrm{E}$ protein to identify compounds with antiviral activity against multiple flaviviruses. The biological evaluation of the most promising compounds obtained from the computer-based simulation revealed that compound $\mathbf{3 3}$ containing the urea moiety, has antiviral activity against both WNV and yellow fever virus. Comparing to other studied compounds, it was suggested that that linkage of thiazole ring via urea/hydrazone to a large aromatic group is the key components for antiviral activity [32].

Obtained potent antitumor compounds utilizing biomass building blocks

Cancer is one of the most dangerous diseases that threaten humanity. Although several drugs are used with different structures and mechanisms of antitumor activities, they failed to defeat cancer completely due to the development of drug resistance, side effects and failure of antitumor drugs to exert their effects in certain cases of cancer. Therefore, seeking for new chemotherapeutic agents via synthetic or natural origins is one of the most topics of concern to the scientific researchers.

Among the great efforts done, a new series of thioglygosideoxadiazole $\mathbf{3 5}$ derivatives was synthesized. Compounds $\mathbf{3 5}$ and $\mathbf{3 6}$ showed potent antitumor activity when tested against different cell lines [26,33,34]. The (SAR) studies for compound 35a with other fatty derivatives demonstrate that the fatty chain in the synthesized compounds plays a crucial role in their biological activities. The increase in the number of carbon atoms of the side chain increases the antitumor activity. The molecular Docking study showed that the activity of compound 35a is due to its good interaction with amino acids and it exhibited good fitting in the binding sites [26]. 


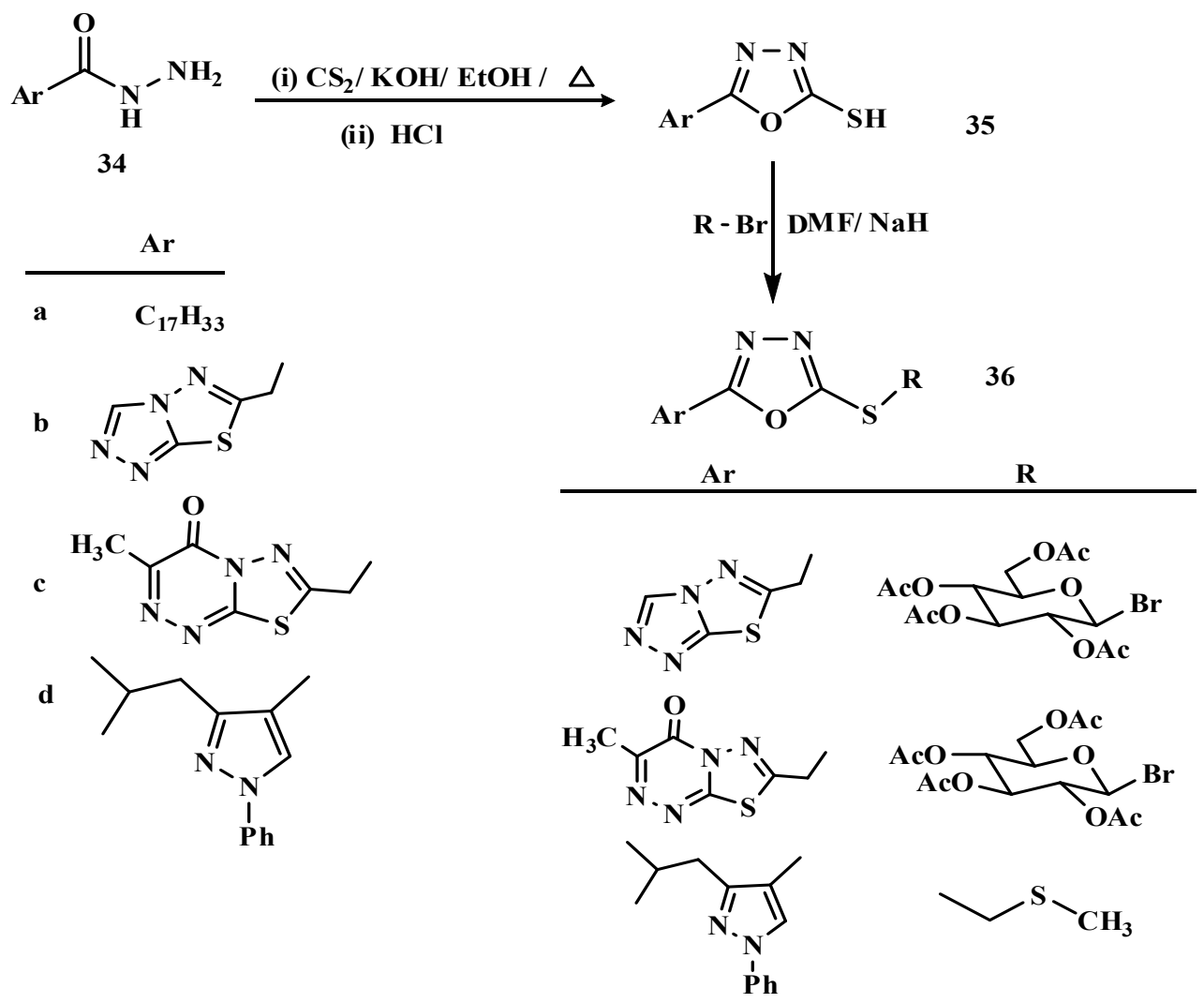

Scheme 10: New series of thioglycoside oxadiazole derivatives as potent antitumor agents.

In continuation to our work, we reported the identification of a series of compounds with anticancer activity by a combined virtual screening approach on the kinase domains of HER1 and HER2 which are considered important targets in anticancer therapy with dual HER1/ HER2 inhibitor. The newly synthesized 1,4 disubistitutedthiosemicarbazide 39, obtained from naturally occurring 3-indole acetic acid, exhibited high antitumor activity. In addition, The ELIS Assay suggested that compound $\mathbf{3 9}$ could target HER 1 and HER2 kinase domains and represent a good starting point for the development of novel anticancer compounds. However, further studies will be needed to confirm the mode of action of this compound [35].

Because of the high reactivity of 3-oxoalkanocarboxylates as polyfunctional compounds, we directed our work utilizing some of them to synthesize new heterocyclic compounds. Acetylated glycine, for example, was utilized via a simple route for the synthesis of various heterocyclic compounds [36-38]. Following this route, reaction of cyanoacetyl glycine 40 with different aldehydes resulted in the synthesis of new series of ylidines which are active precursors for the new compounds $\mathbf{4 2}$ and 43 that exhibit potent antitumor activity [14].<smiles>Cc1ccccc1CC(=O)NN</smiles>

Scheme 11: Lead antitumor agent utilizing indole incorporating ur eayl residue. 


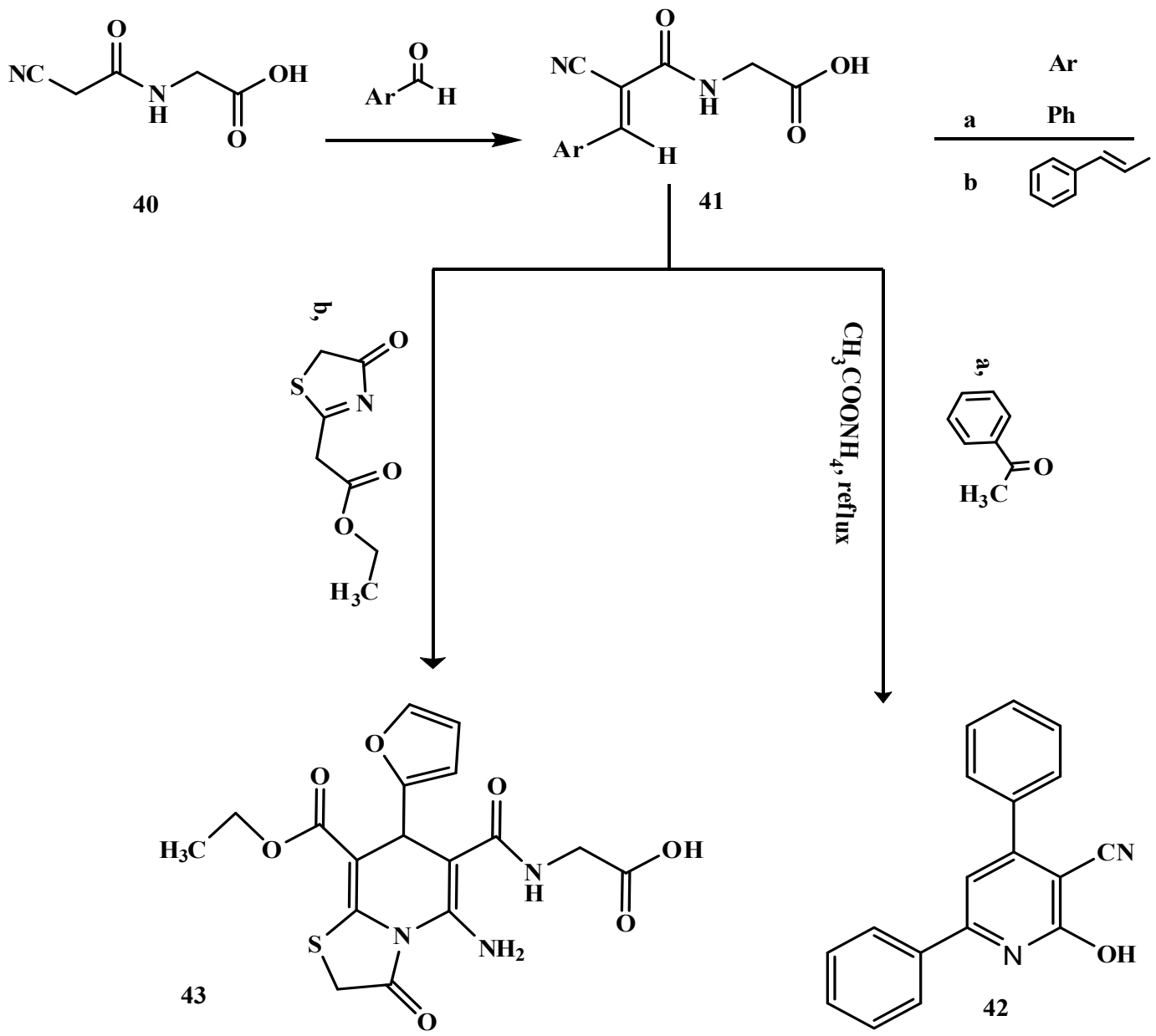

Scheme 12: Synthesis of lead antitumors 42 and 43.

Analgesic and Anti-inflammatory obtained leads Recently, pyrimidines derivatives have generated great interest due to their wide spectrum biological activity. There is a large number of pyrimidinebased antimetabolites. They are usually structurally related to endogenous substrates they antagonize. The structure modification may be on the pyrimidine ring or on the pendant sugar groups. In the hope of finding more effective analgesic and anti-inflammatory drugs, we directed our attention to synthesize new derivatives of $S$-glycosidothieno $[2,3-d]$ pyrimidine. Among the compounds examined in our study, were compounds $48 \mathbf{a}, \mathbf{b}$ and 50a-c which possess the most prominent and consistent activity. It was clear that compounds bearing 2-(b-D-ribofuranosylthio)residues 48a,b displayed the best activity. By contrast, 2-(b-Dgalactopyranosyl-thio)-50a-c analogs were less active. It can be hypothesized that the larger substituent causes decrease in the activity for this series and may be detrimental to the overall activity. Among the compounds, it was appeared that presence of an ethyl carboxylate substituent in position-6 of the 3-aminothieno[2,3- $d]$ pyrimidine nucleus led to more active compounds (48a and 50a,b) compared with acetyl substituted derivatives in the same position of 3-aminothieno[2,3-d]pyrimidine (48b and $\mathbf{4 9 c})$ [39].

In continuation to elucidate effective analgesic and anti-inflammatory therapeutics, we started our work utilizing precursors with pyrimidine moiety. Heterocycles bearing a symmetrical pyrimidoquinoline moiety are reported to show a broad spectrum of pharmacological and medicinal properties including analgesic and anti-inflammatory activities. In addition, 
Microtechnology has attracted much interest for the rapid synthesis of organic compounds which are not easily accessible by conventional synthetic techniques. Therefore, we applied Microwave techniques to synthesize the starting material of our new (2-thioxy-pyrimido[4,5-b]quinoline) derivatives. Compounds 55a,b and 57a,b showed more potent anti-inflammatory and analgesic activities [40].

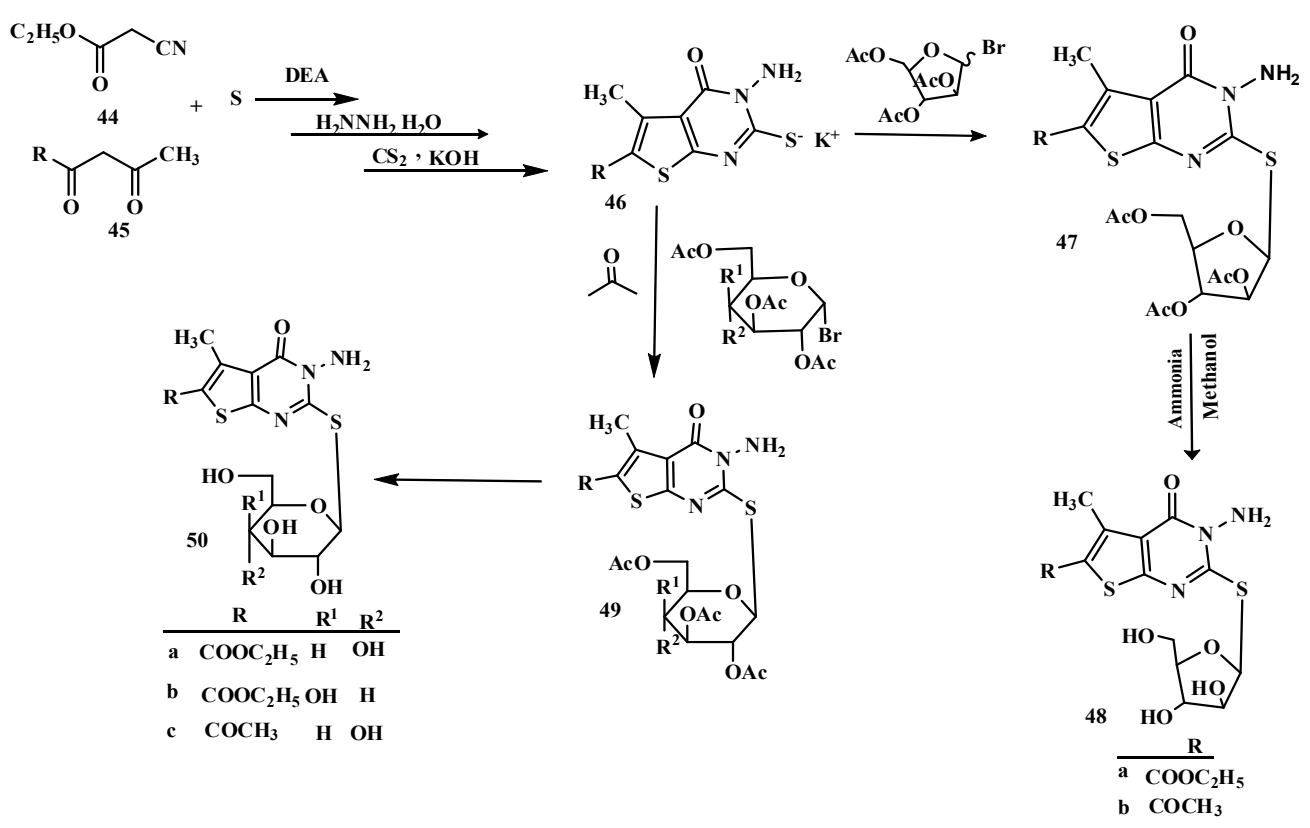

Scheme 13: Synthetic route for $S$-glycosido-thieno[2,3-d] pyrimidine as potent analgesic and antiinflammatory .

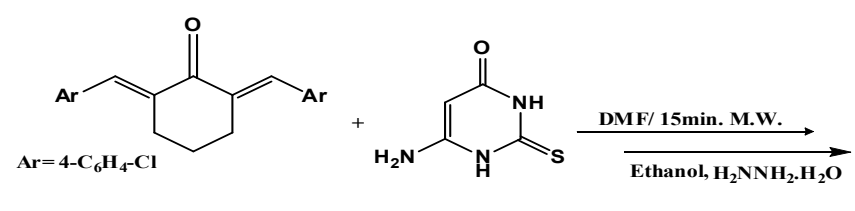

51

52

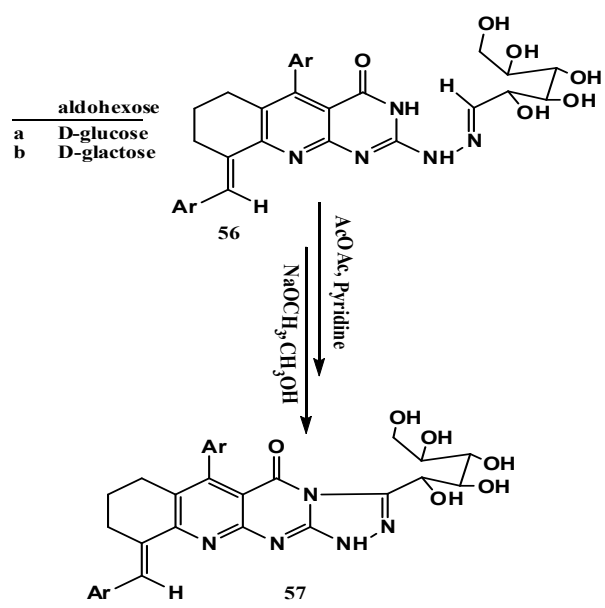

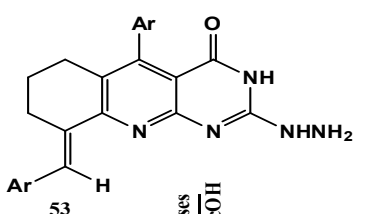

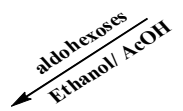

Ar 53
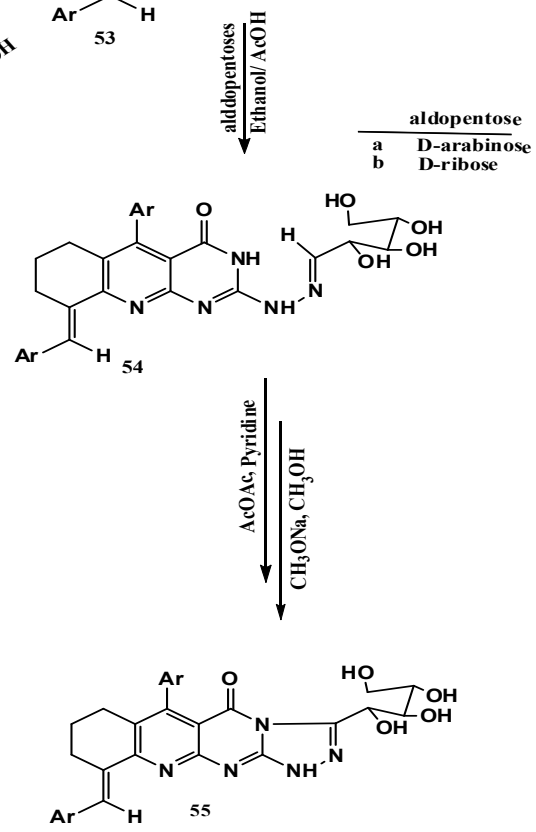

Scheme 14: 2-thioxy-pyrimido[4,5-b]quinoline derivatives as lead antiinflammatory and analgesic .

Egypt. J. Chem. 61, No.5 (2018) 
In addition, new benzimidazole and imidzopyridine derivatives were designed and synthesized from their corresponding oximes 25. The newly synthesized compounds were investigated in vivo for their anti-inflammatory and analgesic activities. Some of the new compounds 26c-e showed reasonable anti-inflammatory and analgesic activity in experimental rats in comparing to indomethacin and Diclofenac $\mathrm{Na}$, as reference drugs. Compounds 26c-e were found to be potent anti-inflammatory and analgesic agents with percent Oedema inhibition $(33.92 \%, 33.92 \%$ and $37.63 \%$ ). And protection percent as analgesic agents $(68.84,75.04 \%$ and $77.04 \%)$ respectively. In particular, compound 26e showed the most potent anti-inflammatory and analgesic activity. Moreover, docking studies of compounds that have highest anti-inflammatory activity showed that compound 26e displayed stronger binding interactions with the active site of the human

\section{COX-2 enzyme (cf. Scheme 6 ) [25].}

\section{Discovered lead Molluscidial molecules}

In continuation to our work aiming to develop new heterocyclic systems with expected biological potentialities from biomass driven starting materials, we were seeking for new compounds with molluscisidal activity in a trial to solve many health problems in our country. 1-(2-hydroxy/substituted phenyl)-3-(2-furyl) propenone 58 was tested as moluscicidal agent and it showed the most promising result. In an attempt to improve its activity, new derivatives of it were synthesized. As oximes are known for their biological importance, the propenone $\mathbf{5 8}$ was treated with $\mathrm{H}_{2} \mathrm{NOH} . \mathrm{HCl}$ in aqueous-methanolic $\mathrm{KOH}$ solution, affording compound $\mathbf{5 9}$ which exhibited most effective molluscicidal activity [41].<smiles>NC(=O)OCc1ccco1</smiles>

\section{Scheme 15: Synthesis of new derivatives of 1-(2-hydroxy/substituted phenyl)-3-(2-furyl) propenone with} molluscicidal activity.

As it's known that salicylanilides represent an important class of molluscicides, we reported the treatment of5-chloro-2-hydroxybenzoyl chloride 60 with piperidine and formaldehyde in a Mannich type reaction affording the corresponding
3-(N-piperidinomethyl)salicylanilides61. The toxicity of this product to Biomphalaria Alexandria snails was evaluated and the result showed that compound $\mathbf{6 1}$ is the most effective. [42]<smiles>O=C(Cl)c1cc(Cl)ccc1O</smiles>

60

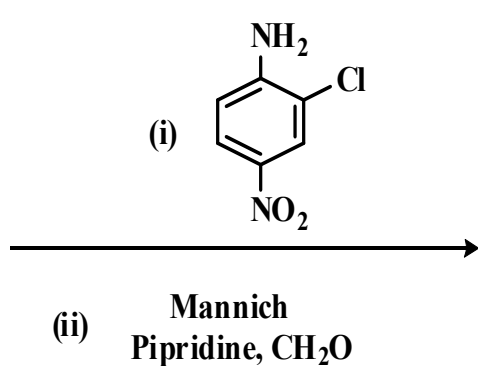

Pipridine, $\mathrm{CH}_{2} \mathrm{O}$

Scheme 16: Synthesis of the most effective molluscicidal 3-( $N$-piperidinomethyl)salicylanilides.<smiles>O=C(Nc1ccc([N+](=O)[O-])cc1Cl)c1cc(Cl)cc(CN2CCCCC2)c1O</smiles>

61 
On the other hand, we constructed new salicyloyl amino acid conjugates utilizing Mannich reaction, as amino acid conjugations are known to improve the pharmacokinetics and toxicity of active drug. The toxicity of the producttoBiomphalariaalexandria snails was evaluated and the result showed that the salicylanilide containing the $N$-glycinomoiety 63 has the same Molluscicidal activity as the known mollusicide Pilocid but without the disadvantage of Pilocid a raised from its bad water solubility [43].

The structure activity relationship studies showed that the acidity of salicylanilide moiety is an important feature in its molluscicidal activity. Accordingly, the 3-nitro derivatives were chosen as starting compounds for the synthesis of new salicylanilides. Water solubility and biodegradability were considered as disadvantages in the Pilocidmolluscicide. Pyrimidosalicylanilide $\mathbf{6 6}$ with potent molluscicidal activity was designed and synthesized as a heterocyclic analogue hoping to overcome these disadvantages. It was synthesized starting with malonic acid derivative $\mathbf{6 4}$, followed by acylating urea to give $\mathbf{6 5}$. To a solution of compound $\mathbf{6 5}$ in DMF, NaH was added followed by the addition of 3,4-dichlorophenyl isocyanate to afford compound $\mathbf{6 6}$ which showed promising molluscicidal activity [44].<smiles>Cc1ccc([N+](=O)[O-])c(Cl)c1NOc1cc(Cl)ccc1O</smiles>

62<smiles>CCCCc1cc(Cl)cc(Cl)c1OC(=O)O</smiles>

Scheme 17: Better slouble pilocidQ derivative.<smiles>NC(=O)NC(=O)CC(=O)Nc1ccc([N+](=O)[O-])cc1Cl</smiles><smiles>O=C(Nc1ccc([N+](=O)[O-])cc1Cl)c1c(O)n(-c2ccc(Cl)c(Cl)c2)c(=O)[nH]c1=O</smiles>

Scheme 18: Heterosalicylanilide analouge as lead molluscicide. 
The idea of preparing new azoles carrying the 2,4-dichlorophenoxy moiety which has herbicidal activity seemed to be interesting. Therefore, hoping to obtain compounds that combat snails and water hyacinth shelter in the same time. Compounds 70, 71 and 72 showed most promising Molluscicidal activity [45].

Lead Insecticidal molecules via the same above mentioned approach

Recycling of solid waste (PET) using sunlight to afford new bis (1,3,4-oxadiazole) 74 and1,3thiazolidine derivatives $\mathbf{7 5}$ via utilizing (PET) monomer terephthalic acid which esterified and treated with hydrazine hydrate to afford the corresponding hydrazide that coupled with carbon disulphide to give adduct 73. Interestingly, these compounds $\mathbf{7 4}$ and $\mathbf{7 5}$ exhibited good in-vitro insecticidal activity against the Cluexpipiens and Muscadomestica [46].<smiles>O=C(Cl)COc1ccc(Cl)cc1Cl</smiles>

67

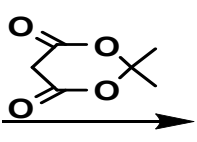

Pyridine<smiles>[R]C1=NN(c2ccccc2)C(=O)/C1=N\OO</smiles><smiles>CCC(C)C(=O)ON=O</smiles><smiles>[R]=[SiH]c1ccc(OC)c(Cl)c1</smiles><smiles>CC1(C)OC(=O)C(C(=O)COc2ccc(Cl)cc2Cl)C(=O)O1</smiles><smiles>CC(C)(O)O</smiles><smiles>CCOC(=O)CC(=O)Oc1ccc(Cl)cc1Cl</smiles><smiles>C#Cc1ccccc1</smiles>

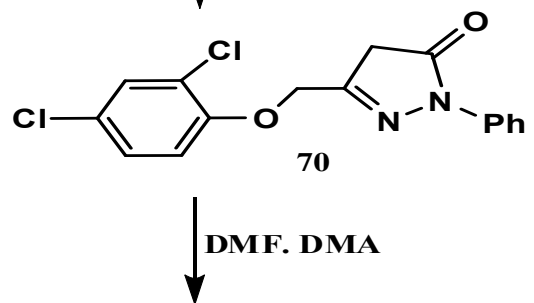<smiles>[R]C1=NN(c2ccccc2)C(=O)/C1=C/N(C)C</smiles>

Scheme 19: Design and sythesis of potent moll uscicides having herbicidal activity.

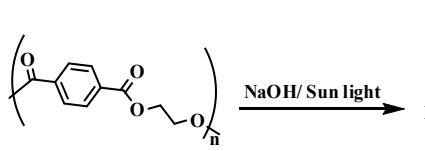<smiles>O=C(O)c1ccc(C(=O)O)cc1</smiles>

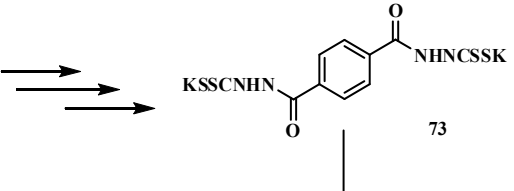
$\sqrt{\mathrm{PhCOCH}_{2} \mathrm{Br}}$ $\mathrm{C}_{2} \mathrm{H}_{5} \mathrm{OCOCH}_{2} \mathrm{Br}$

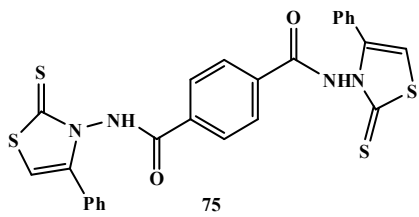<smiles>CCOC(=O)CSc1nnc(-c2ccc(-c3nnc(SCC(=O)OCC)o3)cc2)o1</smiles>

Scheme 20: Valorization of PET wasteand produce potant insecticiads. 
Besides, a series of quinolone derivatives have been elaborated and showed Anti Aphid Aphis gossypii that harm cotton crop in Egypt. Compound $\mathbf{8 0}$ was found to be more active than Marshal (Carbosulfan), one of the broad insecticides widely used in this field. It was synthesized by the nucleophilic substitution of 2-chloroquinoline $\mathbf{7 6}$ with the appropriate acetylaniline derivative 77 in refluxing $\mathrm{EtOH}$ containing drops of $\mathrm{HCl}$ to afford compound $\mathbf{7 8}$. Thus, compound $\mathbf{7 8}$ was heated under reflux with thiosemicarbazide to give compound $\mathbf{7 9}$ which when heated under reflux in benzene and ethanol, the desired compound $\mathbf{8 0}$ was obtained [47].<smiles>Nc1ccc([R](=O)O)cc1</smiles><smiles>ONc1cccc([R](Cl)Cl)c1</smiles><smiles>CC(=O)O[Na]</smiles>

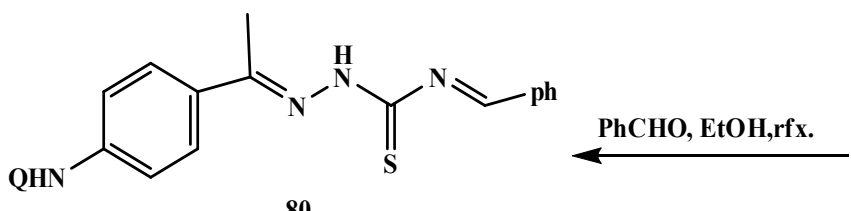<smiles>[R]c1ccc(NO)cc1</smiles>

$\mathrm{R}=4-\mathrm{C}\left(\mathrm{CH}_{3}\right)=\mathrm{NNHC}(\mathrm{S}) \mathrm{NH}_{2}$

Scheme 21: Lead Anti Aphid.

\section{Obtained lead Antioxidants}

An antioxidant is a molecule that inhibits the oxidation of other molecules which is a chemical reaction that can produce free radicals, leading to chain reactions that may damage cells. Antioxidants such as thiols or ascorbic acid (vitamin C) terminate these chain reactions.
One of the several efforts that have been done to obtain new antioxidants, is a study carried out on the new heterocyclic compounds 82 and $\mathbf{8 3}$ activities and proved their efficiency as antioxidants on styrene butadiene rubber (SBR) mixes [48].<smiles>Cc1c(-n2cc(C#N)c(=O)[nH]c2=O)c(=O)n(-c2ccccc2)n1C</smiles>

Scheme22: lead antioxidant having insecticidal activity for industrial use.

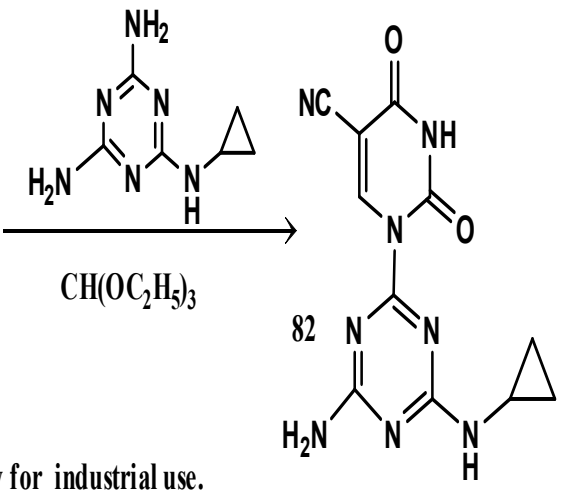


In the same context, the protective effects of the synthetic antioxidant "acetylgallate derivative" (SAC) 84 were investigated against hepatic oxidative stress and brain damage induced by dimethoate (DM) in male rats. The result showed that supplementation of SAC is more reliable than Vitamin $\mathrm{C}$ in attenuating relative liver weight, SOD, GST, and brain DNA damage [49].

In addition, Compounds11and $\mathbf{1 2}$ (cf. Scheme 3) resulted from the recycling/management of poly ethylene terephthalate(PET) waste exhibited good radical radical scavenging activity [50].

In the same context, fatty acids are derived from renewable raw materials and exhibit various biological activities. Several researchers are amalgamating these bioactive components with heterocyclic compounds to yield bioactive hybrid molecules with some desirable features. Heterocyclic fatty acid hybrid derivatives are a new class of heterocyclic compounds with a broad range of biological activities and significance in the field of medicinal chemistry. New series of 3-olyl-6-substituted[1,2,4] triazolo[3,4-b]thiadiazoles, 3-olyl-6-substituted [1,2,4]-triazolo[3,4-b]thiadiazines, and $S$ - or $\mathrm{N}$-substituted 3-mercapto-1,2,4-triazoles was synthesized starting with oleic acid. Among the different compounds synthesized, compound $\mathbf{8 5}$ which is an analogue to vitamin $\mathrm{C}$ (ascorbic acid) showed high antioxidant activity [15].<smiles>C/C(=N\NC(=O)CC#N)c1ccc(O)c(O)c1O</smiles>

84

Scheme23: Potent antioxidant utilizing pyrogallol.<smiles>[CH]c1nnc(S)n1N</smiles><smiles>CC(Cl)(Cl)Oc1cc(C(=O)O)cc(O)c1O</smiles>

$\mathrm{POCl}_{3}$

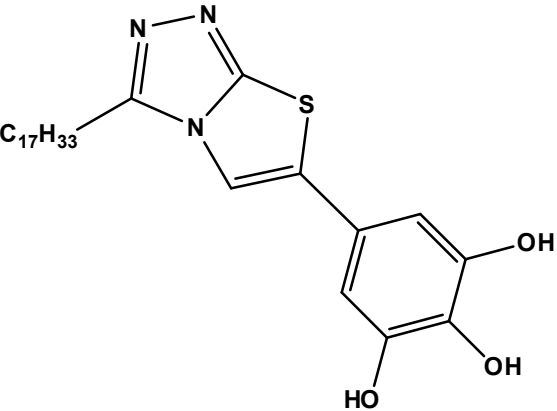

85

Schemec 24: Developing the antioxidant activity of gallic acid via incorporating heterocyclic moiety.

\section{Conclusion}

Our future sustainability creates a great challenge in sciences and technologies. The exploration of new fundamental chemical reactivates could potentially result in chemical tools that are more efficient in resource and energy utilization with less accumulation of waste. The examples presented in this review illustrate our efforts toward the low-cost discovery via chemical synthesis with an eye on future sustainability. Simple synthetic routes and processes utilizing waste driven building blocks could present a low cost strategy for inventing novel solution for different chronic health, agricultural and industrial problems in Africa and other developing countries. Cooperation between developed country and African countries for example will allow quick application of the newborn low cost discoveries. The waste-based bio-economy is an important component of the transition from a linear - take, make, dispose economy to a sustainable circular economy. 


\section{Acknowledgment}

The authors have to express their gratitude to Dr. Laila M. Chabacka for her passed effective part in our research group.

\section{References}

1. Maria Dolores Martín Bermudo, Luka Gebel, and Isabel M. Palacios. DrosAfrica: Building an African Biomedical Research Community Using Drosophila. Seminars in Cell \& Developmental Biology, 70, 58 (2017).

2. World Bank and Elsevier.A Decade of Development in Sub-Saharan African Science, Technology, Engineering \& Mathematics research.

3. UN-DESA and the OECD. World Migration in Figures (2013).

4. Klaus Schwab, World Economic Forum. The Global Competitiveness Report (2017-2018).

5. Weiping Deng, Ye Wang, Ning Yan. Production of Organic Acids from Biomass Resources. Current Opinion in Green and Sustainable Chemistry, 2, 54 (2016).

6. Mizuho Yabushita, Hirokazu Kobayashia, Atsushi Fukuoka. Catalytic Transformation of Cellulose into Platform Chemicals. Applied Catalysis B: Environmental, 145,1(2014).

7. José Goldemberg. Ethanol for a Sustainable Energy Future.Science, 315, 808 (2007).

8. Roger A. Sheldon. Green Chemistry, Catalysis and Valorization of Waste Biomass. Journal of Molecular Catalysis A: Chemical, 422, 3 (2016).

9. Feng Peng, Pai Peng, Feng Xu, Run-Cang Sun. Fractional Purification and Bioconversion of Hemicelluloses. Biotechnology Advances, 30, 879(2012).

10. Ming-Zhi Zhang, Qiong Chen, Guang-Fu Yang. A review on recent developments of indole-containing antiviral agents. European Journal of Medicinal Chemistry, 89, 421 (2015).

11. Yanling, Liang Xin and $\mathrm{Li}$ Zhiyuan. The Antibacterial Drug Discovery, Jie, IntechOpen. chapter 10, 289 (2013).

12. Min Qiao, Guang-Guo Ying, Andrew C. Singer,
Yong-Guan Zhu.Review of Antibiotic Resistance in China and Its Environment. Environment International, 110, 160 (2018).

13. World Health Organization.Antimicrobial Resistance Global Report on Suveillance(2014).

14. Nora M.A.El-Ebiary, Emad M. El-Telbani, RandaH.Swellem, Ibrahim F. Zeid and Galal A.M. Nawwar. Design, Synthesis, Crystal Structure, and Antimicrobial Evaluation of Novel Pyrazolyl - 1,3,5-Oxadiazoles, Pyrazolyl-1,2,4-triazoles and their Related Thioglycosides. Letters in Drug Design \& Discovery, 10, 444 (2013).

15. Hayam A. Abd El Salam, El-Sayed M.A. Yakout, Galal A.M. Nawwar, Maher A. El-Hashash and Abd El-Tawab H. Mossa. Synthesis of Some New 1,2,4-triazoles Containing Olyl Moiety and Evaluation of their Antimicrobial and Antioxidant Activities. Monatshefte für Chemie. 148, 291 (2017).

16. Hoda S. Othman, RandaH. Swellem, Ali S. Hebishy, Galal H. Elgemeie and GalalA.M.Nawwar. Amino Acid Derivatives in Organic Synthesis Part 5: Design and Facile Synthesis of Difficult Accessible Compounds and Determination of Their Antitumor and Antimicrobial Activities. World Journal of Chemistry. 10, 01 (2015).

17. Asmaa M. Fahim, Ahmed M. Farag, and Galal A.M. Nawwar. PET Waste Recycling as Chemical Feedstock: Synthesis and Antimicrobial Activity of New Compounds with Anticipated Industrial Use. Journal of Applicable Chemistry, 2, 502 (2013).

18. Leho Tedersoo et al. Global diversity and geography of soil fungi. Science, 346, 1078 (2014).

19. Monica A. Garcia-Solache, Arturo Casadevall. Global Warming Will Bring New Fungal Diseases for Mammals. Opinion/Hypothesis, 1, 1 (2010).

20. Abad, María José, AnsuateguiMaría, BermejoBenito Paulina.Active Antifungal Substances from Natural Sources. Arkivoc, 2007, 116 (2007).

21. Frank L. van de Veerdonk, Bart-Jan Kullberg and Mihai G. Netea.Pathogenesis of Invasive Candidiasis.Current Opinion in Critical Care, 16, 453, (2010).

22. Bart Jan Kullberg, and Maiken C. Arendrup. Invasive Candidiasis. The New England Journal of Medicine, 373, 1445 (2015). 
23. Galal A.M. Nawwar and Nancy A. Shafik. Synthesis of 2-Substituted Benzothiazoles Containing Amino Acid, Imino or Hetero Aryl Moieties with Anticipated Fungicidal Activity. Collectection of Czechoslovak Chemical Communications. 60, 2200 (1995).

24. Emad M. El-Telbani, Randa H. Swellem, and Galal A.M.Nawwar. FacileSynthesis of 6-Hetaryl-[1,2,4] Triazolo[3,4-b][1,3,4] thiadiazoles and 7Hetaryl[1,3,4]thiadiazolo[2,3-c][1,2,4]triazines with Fungicidal Activity. Russian Journal of Organic Chemistry, 43, 1815 (2007).

25. Galal A. M. Nawwar, Nabil M. Grant, Randa H. Swellem and Samia A. M. Elseginy. Design, Synthesis, Docking and Evolution of FusedImidazolesas Anti-inflammatory and Antibacterial Agents. DerPharmaChemica, 5, 241(2013).

26. Fatma Salah EL-Din Mohamed, Ahmed Ismail Hashem, Randa Helmy Swellem and Galal Abd El-Moaen Mohamed Nawwar. Synthesis, Evaluation and Molecular Docking Studies of 1,3,4-oxadiazole-2-thiol Incorporating Fatty Acid Moiety as Antitumor and Antimicrobial Agents. Letters in Drug Design\& Discovery, 11, 304 (2014).

27. Ming-Zhi Zhang, Qiong Chen, Guang-Fu Yang. A Review on Recent Developments of IndoleContaining Antiviral Agents. European Journal of Medicinal Chemistry, 89, 421 (2015).

28. Ling Chen, Gangliang Huang. The Antiviral Activity of Polysaccharides and Their Derivatives. International Journal of Biological Macromolecules, 115, 77(2018).

29. Qing-Yin Wang, Sejal J. Patel, Eric Vangrevelinghe, et al. ASmall Molecule Dengue Virus Entry Inhibitor. Antimicrobial Agents and Chemotherapy, 53, 1823 (2009).

30. Larry E. Davis, MD,RobertaDeBiasi, MD, Diane E. Goade, et al. West Nile Virus Neuroinvasive Disease. Annals of Neurolog, 60, 286 (2006).

31. Paul R. Young, Thorsten Kampmann, Ragothaman Yennamalli et al. In Silico Screening of Small Molecule Libraries Using the Dengue Virus Envelope E Protein Has Identified Compounds with Antiviral Activity Against Multiple Flaviviruses. Antiviral Research, 84, 234 (2009).

32. Samia A. Elseginy, Alberto Massarotti, Galal A.M. Nawwar, Kamilia M Amin and Andrea
Brancale. Small Molecule Inhibitors of West Nile Virus. Antiviral Chemistry and Chemotherapy, 23, 179, (2014).

33. Mamdouh A.Z.Abu-Zaied, Galal A.M. Nawwar, Randa H. Swellem, Shahinaz, H. El-Sayed. Synthesis and Screening of New 5-substituted1,3,4-oxadiazole-2-thioglycosides as Potent Anticancer Agents. Pharmacology \& Pharmacy, 3, 254 (2012).

34. Mamdouh A.Z. Abu-Zaied, Emad M. El-Telbani, Galal H. Elgemeie and Galal A.M. Nawwar. Synthesis and in vitro Antitumor Activity of new OxadiazoleThioglycosides. European Journal of Medicinal Chemistry, XXX, 1 (2010).

35. Samia A. Elseginy, Glorianne Lazaro, Galal A.M. Nawwar, Kamilia M. Ami, Stephen Hiscox and Andrea Brancale. Computer-aided Identification of Novel Anticancer Compounds with a Possible dual HER1/HER2 Inhibition Mechanism. Bioorganic\& Medical Chemistry Letters, 25, 758 (2015).

36. Yehia A. Allam, Randa H. Swellem and Galal A. M. Nawwar. Cyanoacetylurea in Heterocyclic Synthesis: A Simple Synthesis of Heterocyclic Condensed Uracils. Journal of Chemical Research, 8, 346 (2001).

37. Randa H. Swellem, Laila M. Chabaka and Galal A.M. Nawwar. Cyanoacetylation as a simple route for difficult accessible pyrimidines. Egyptian Journal of Chemistry,5 0, 135 (2007).

38. HodaSabry Othman, Maher Al-Hashash and Galal Abd El-Moein Nawwar.Cyanoacetyl Urea in Heterocyclic Synthesis Part V: Facile Synthesis of Poly-functionalized Pyrimdines via Different Behaviors of its Free Urea Amino group. Egyptian Journal of Chemistry, 61, 180(2018).

39. Hend N. Hafez, Abd El-Rahman B.A. El-Gazzar and Galal A.M. Nawwar. Synthesis, Biological and Medicinal Significance of $S$-glycosido-thieno[2,3d]-pyrimidines as New Anti-inflammatory and Analgesic Agents. European Journal of Medicinal Chemistry, XXX,1 (2010).

40. Abd El-Rahman B.A. El-Gazzar, Hend N. Hafez and Galal A.M.Nawwar. New Acyclic Nucleosides Analogues as Potential Analgesic, Antiinflammatory, Anti-oxidant and Anti-microbial Derived from Pyrimido[4,5- $b$ ] quinolines. European Journal of Medicinal Chemistry, 44, 1427 (2009).

Egypt. J. Chem. 61, No.5 (2018) 
41. Galal A.M. Nawwar, Bahiga M. Haggag and Randa H. Swellam. Synthesis and Molluscicidal Activity of New Derivatives of 1-(Hydroxy/ Substituted Phenyl)-3-arylpropenones. Archiv Der Pharmazie(Weinheim), 326, 831(1993).

42. Galal A.M. Nawwar, Randa H. Swellem and Amal M. Ibrahim.Oxazole, Pyrazole and Piperidine Derivatives Having an O-Hydroxy-aryl Moiety with Anticipated Molluscicidal Activity. Archives of Pharmacal Research, 17, 66 (1994).

43. Galal A.M. Nawwar. Salicylamides Containing Amino Acid or Pyran Moieties with Molluscicidal Activity. Archiv Der Pharmazie (Weinheim), 327, 201(1994).

44. Laila M. Chabaka, Nancy E. Shafik and Galal A.M. Nawwar. Salicylanilides and their Heterocyclic Analogues with Molluscicidal Activity, Afinidad, 63, 241 (2006).

45. Emad M. El-Telbani, Mohamed F. El Shehry, and Galal A.M. Nawwar. Meldrum's Acid in Heterocyclic Synthesis: Azole Incorporating a 2,4-dichlorophenoxy Moiety with Anticipated Molluscicidal Activity. Monatshefte für Chemie. 139, 685 (2008).

46. Asmaa M. Fahim, Omnia M. Kamel and Galal A.M. Nawwar. Facile Synthesis of In-Vivo Insecticidal and Antimicrobial Evaluation of Bis
Heterocyclic Moiety from PET waste. Online Journal of Biological Sciences, 14, 196 (2014).

47. Mohamed Ramdan El-Sayed Aly, Ahmed Elsayed Mahmoud Abd El-Mageed, Abdel Kader Mousa Abdel El Kafafy and Galal A.M. Nawwar. Synthesis and Anti-Aphid Aphis Gossypii Glover Activity Quinoline Derivatives. Journal of Plant Protection Research, 51, 114 (2011).

48. Galal A.M. Nawwar, Sayed Yakout and M.S.A. El-Sadiek. Synthesis and Evaluation of New Antioxidants for Styrene Butadiene Rubber. Pigment\& Resin Technology, 40, 399 (2011).

49. Tarek M. Heikal, Abdel-Tawab H. Mossa, Galal A.M. Nawwar, Mahmoud El-Sherbiny and Hassan Z. Ghanem. Protective Effect of a Synthetic Antioxidant "Acetyl Gallate Derivative" Against Dimethoate Induced DNA Damage and Oxidant / Antioxidant Status in Male Rats. Environmental\& Analytical Toxicology, 2, 2 (2012).

50. Asmaa M. Fahim, El-Sayed M.A. Yakout, EmanA.Ragab, Ahmed M. Farag and Galal A.M. Nawwar. Synthesis, Biological Evaluation of 1,3,4-Oxadiazole, Triazole and Uracil Derivatives from Poly (ethylene terephthalate) Waste. Egyptian Journal of Chemistry, 59, 285 (2016).

(Received 10/5/2018; accepted $1 / 8 / 2018$ )
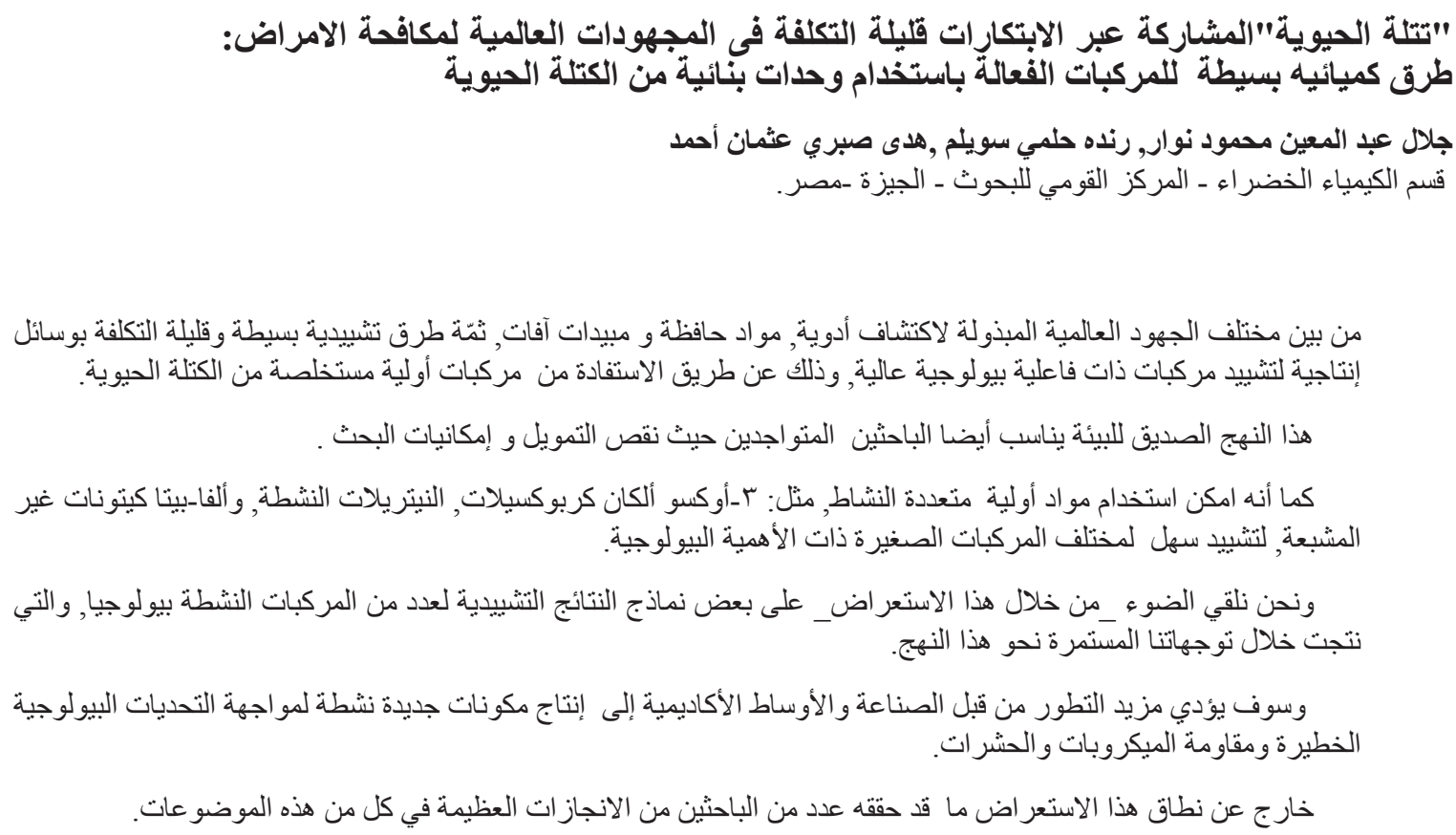